Article

\title{
Application of Moving Bed Biofilm Reactor and Fixed Bed Hybrid Biological Reactor for Oilfield Produced Water Treatment: Influence of Total Dissolved Solids Concentration
}

\author{
Nicolas Lusinier ${ }^{1}$, Isabelle Seyssiecq ${ }^{2}$, Cecilia Sambusiti ${ }^{3}$, Matthieu Jacob ${ }^{3}$, Nicolas Lesage ${ }^{4}$ \\ and Nicolas Roche $1,5, *$ (i)
}

\section{check for} updates

Citation: Lusinier, N.; Seyssiecq, I.; Sambusiti, C.; Jacob, M.; Lesage, N.; Roche, N. Application of Moving Bed Biofilm Reactor and Fixed Bed Hybrid Biological Reactor for Oilfield Produced Water Treatment: Influence of Total Dissolved Solids Concentration. Energies 2021, 14, 7297 https://doi.org/10.3390/en14217297

Academic Editor: Nguyen Van Duc Long

Received: 23 August 2021

Accepted: 19 October 2021

Published: 4 November 2021

Publisher's Note: MDPI stays neutral with regard to jurisdictional claims in published maps and institutional affiliations.

Copyright: (c) 2021 by the authors. Licensee MDPI, Basel, Switzerland. This article is an open access article distributed under the terms and conditions of the Creative Commons Attribution (CC BY) license (https:/ / creativecommons.org/licenses/by/ $4.0 /)$.
1 Aix-Marseille Université, CNRS, IRD, INRAE, Coll France, CEREGE, 13545 Aix en Provence, France; lusinier@cerege.fr

2 Aix Marseille Université, CNRS, Centrale Marseille, M2P2, 13411 Marseille, France; isabelle.seyssiecq@univ-amu.fr

3 Total SA, PERL-Pôle d'Etudes et de Recherche de Lacq, Pôle Economique 2, BP 47-RD 817, 64170 Lacq, France; cecilia.sambusiti@totalenergies.com (C.S.); matthieu.jacob@totalenergies.com (M.J.)

4 Total SA, CSTJF, Avenue Larribau, 64000 Pau, France; nicolas.lesage@totalenergies.com

5 International Water Research Institute, Mohammed VI Polytechnic University, Benguerir 43150, Morocco

* Correspondence: nicolas.roche@univ-amu.fr

\begin{abstract}
This experimental paper deals with the development of a hybrid biological reactor for the treatment of a synthetic oilfield produced water under an increase in total dissolved solids (TDS) concentration. To comply with strengthening regulations concerning produced water discharge and peculiar produced water compositions, a moving bed biofilm reactor (MBBR) consisting in a combination of free activated sludge and moving biofilm supports was compared to a fixed bed hybrid biological reactor (FBHBR) consisting in a combination of free activated sludge and a fixed biofilm support. After a 216 days experimental period, the MBBR and the FBHBR were efficient to treat a synthetic produced water with chemical oxygen demand (COD) removal rate above $90 \%$ under an increase in TDS concentrations from 1.5 to $20 \mathrm{~g} \cdot \mathrm{L}^{-1}$. Ecotoxicity measurements on freshwater and marine microorganisms revealed an absence of toxicity on treated waters. A decrease in bacterial diversity indices with respect to the inoculum was observed in both bioreactors. This suggests that the increase in TDS concentrations caused the predominance of a low number of bacterial species.
\end{abstract}

Keywords: oilfield produced water; hybrid biological reactor; total dissolved solids; bacterial diversity

\section{Introduction}

Oil and gas activities generate a large amount of wastewater during crude oil and gas extraction. This wastewater, also called produced water (PW) is composed of formation water, initially present in the oil reservoir. Other sources of water may also be added in the reservoir. The resulting outcoming water is then produced water. The ageing of oil reservoirs is currently leading to an increase in PW flowrates [1]. The water to oil ratio (WOR) quantifies this increase. Currently, the WOR is around 3:1, but its value is expected to grow [2].

The composition of produced water is site-specific and depends on several factors [3]. There are three categories of compounds found in PW. Organic compounds regroup dissolved and dispersed hydrocarbons (aliphatic hydrocarbons, carboxylic acids, benzene, toluene, ethylbenzene, xylene (BTEX), polycyclic aromatic hydrocarbons (PAHs), phenol, heavy alkylphenols, heavy hydrocarbons). Inorganic compounds regroup cations and anions (contributing to the salinity of the effluent), trace metals (iron, silver, zinc, chromium, copper, cadmium, mercury and lead) and naturally occurring radioactive materials. Production chemicals are used in PW to insure a proper oil extraction (corrosion inhibitors, biocides, emulsion breakers, asphaltene inhibitors, etc.) [4-7]. 
Currently, the difficult access to water resources in water-stressed area has made oil producers to rethink their management of PW. Whether PW is discharged in the environment or reinjected in oil reservoirs, its quality should meet specific standards $[8,9]$. Concerning PW discharge, regulations are becoming more stringent. It is also worth noting that these regulations are mainly site-specific. In the North Sea, the Convention for the Protection of Marine Environments in the North-East Atlantic (OSPAR) has set the average maximum discharge value for dispersed oil at $30 \mathrm{mg} \cdot \mathrm{L}^{-1}$ [10]. In the United States, the Environmental Protection Agency has set an oil and grease discharge value at $29 \mathrm{mg} \cdot \mathrm{L}^{-1}$ and a daily maximum discharge limit value at $42 \mathrm{mg} \cdot \mathrm{L}^{-1}$. In a recent review, Zheng et al. (2016) summarized existing regulations of PW discharge all around the globe [11]. Recently, regulations started to focus on dissolved hydrocarbons, which cannot be remove from PW with actual treatment technologies. For instance, OSPAR recommendation 2014/5 provides a list of Predicted No effect Concentrations (PNECs) for some compounds found in PW [12]. This should force oil producers to adapt and optimize treatment facilities for a better quality of discharged PW.

PW are currently treated by mean of physico-chemical processes for the removal of dispersed hydrocarbons [13]. However, these processes were not designed to remove dissolved hydrocarbons. Recently, research have been focused on biological treatments [14-20]. Those treatments are considered as a good alternative to physico-chemical processes due to low operating costs. Furthermore, they are considered eco-friendly [21,22]. In these processes, the action of a bacterial consortium in an aerated tank is responsible of the wastewater purification, by taking required nutrients and food for the biomass growth from the wastewater. However, few research reported the application of biological treatment for PW treatment. So far, conventional activated sludge (CAS) reactor, biological aerated filters (BAF), and membrane bioreactors (MBR) were proved to be efficient to treat PW [21-25]. However, these processes were applied under operational conditions not representative of real field conditions. For instance, hydraulic retention times (HRT), i.e., the time that the water is in contact with the purifying biomass, are usually high in previous studies. This is not compatible with field applications where (i) PW flowrates are big and (ii) space allocated to treatments are limited especially on offshore fields.

Another challenge in PW treatment is the high salinity levels in these wastewaters. Measured with total dissolved solids concentration (TDS), this parameter can reach $300 \mathrm{~g} \cdot \mathrm{L}^{-1}$ in PW [26]. The adverse effect of salinity on wastewater biological treatment is well documented in the literature $[27,28]$. High salt content is responsible for cell membranes disruptions, enzymes denaturation and strong osmotic pressure that are lethal to conventional purifying microorganisms. This sensitivity to ionic strength and salt shock loads is responsible for decreases in removal efficiencies and volatile suspended solids. Furthermore, it also causes an increase in effluent suspended solids. One of the major issue in saline conditions is settling issue [29]. Lefebvre and Moletta (2006) reported several effects of salinity on the property of activated sludge. The density of saline water being higher than fresh water, greater resistance to decantation occurs due to high buoyant forces [30]. The lack of versatility of acclimated microorganisms is also pointed out. Once acclimated to saline conditions, it has been noted that bacteria easily lose their efficiency when salinity decreases. Working under hypersaline conditions either implies that the biomass used in the aerated tank has to undergo a well conducted acclimation time with a gradual increase in salinity or the use of halophilic consortia [19-21,26,30].

In the literature authors note obviously that the increase in salinity is associated with the decrease in COD removal. Indeed, the increase in salinity is responsible for biological treatment disturbance, as described before. In more details Sharghi et al. (2013) studied the effect of salinity on a sMBR under a HRT of $48 \mathrm{~h}$ [19]. Their relatively low OLR $\left(0.3-0.9 \mathrm{kgCOD} \cdot \mathrm{m}^{-3} \cdot \mathrm{d}^{-1}\right)$ conjugated with the high HRT and the use of halophilic microorganisms led to high COD removal efficiencies (83\%). It points out the feasibility of PW treatment at high salinity with biological processes. However, all studies reporting high COD removal efficiencies at high salinity were performed with synthetic produced water, 
suggesting that the experimental conditions were still soft enough to allow a good bacterial activity. In this context the study conducted by Pendashteh et al. (2012) revealed that the COD removal efficiency of a eMBR could decrease down to $17 \%$ when the experiments were carried out with real produced water at high salinity (TDS $=250 \mathrm{~g} \cdot \mathrm{L}^{-1}$ ) [21]. This result obtained under a HRT of $48 \mathrm{~h}$, and with the use of halophilic microorganisms showed that there are still investigations needed to understand to what extent salinity can affect the biological treatment of PW. In their work, Pendashteh et al. (2012) only suggested that salinity could affect the biodegradation rate of the dissolved organic compounds.

To answer the challenge brought by the high TDS concentrations, attention should be paid to hybrid processes. These processes contain two or more treatments processes in one reactor. Synergistic effects of the combination of the two treatments may enhance the removal of recalcitrant compounds [31]. In this context, the moving bed biofilm reactor $(\mathrm{MBBR})$ and the fixed bed hybrid biological reactor (FBHBR) are promising to treat PW. Both technologies combine free biomass (activated sludge) and fixed biomass (biofilm) in the same reactor. In the MBBR, the packing material where the biofilm grows is allowed to move freely inside the bioreactor whereas in the FBHBR, the packing material is prevented from moving. These bioreactors have interesting advantages over conventional technologies. With the simultaneous presence of fixed and free biomass, higher biomass concentrations can be reached with respect to conventional technologies. Hybrid biological reactors can also be implemented with small footprints [32,33]. Thus, those processes are of particular interest for offshore implementations. The presence of the biofilm allows the development of slow growing bacteria, which is beneficial for the removal of poorly biodegradable compounds [34]. This type of reactor was proved to be mass transfer efficient and suitable for the treatment of domestic wastewater [35-37].

Dong et al. (2011) were the first to study the treatment of PW in a hybrid biological reactor [38]. Their experiments carried out in a MBBR filled with modified ceramic biocarriers, in order to increase the specific surface area, answered some questions about the development of hybrid biological reactors. Their comparison between a CAS reactor, a MBBR with ceramic biocarriers and a MBBR with modified ceramic biocarriers proved that the hybrid biological processes were better in terms of COD removal. When comparing the two MBBR, the modified ceramic biocarriers allowed a greater extent of biofilm colonization, which maintained high COD removal efficiencies when the HRT was reduced. This suggests a beneficial effect of the specific surface area in hybrid biological reactor. More recently, Hasanzadeh et al. (2020) used walnut shells as biocarriers in a MBBR treating PW [39]. Interestingly, they used halophilic microorganisms to conduct the treatment under high salinity. In their experiments, COD removals were above $70 \%$ even under a salinity of $250 \mathrm{~g} \cdot \mathrm{L}^{-1}$. This was attributed to a beneficial effect of the biocarriers. Authors pointed out that the accumulation of pollutants on the biocarriers allowed a gradual digestion by the biofilm under higher retention time, which maintained a good bacterial activity.

The aim of this experimental study is to demonstrate the efficiency of two hybrid biological reactors (namely a MBBR and a FBHBR) for the treatment of a synthetic PW. Attention was paid to the salinity by gradually increasing TDS concentrations from 1.5 to $20 \mathrm{~g} \cdot \mathrm{L}^{-1}$.

\section{Materials and Methods}

\subsection{Experimental Setup}

The laboratory scale experimental device used for this study was described in a previous study [17]. The experimental pilot is made of two identical cylindrical clear PVC columns as shown in Figure 1a. Both columns provide $30 \mathrm{~L}$ of working volume with an inner diameter of $190 \mathrm{~mm}$ and a total height of $1070 \mathrm{~mm}$. As presented in Figure 1b, the left column was configured as a MBBR. The right column was configured as a FBHBR. The packing material in both the MBBR and the FBHBR was made of cylindrical solid packing rings (AnoxKaldnes ${ }^{\circledR}$, Lund, Sweden) as shown in Figure 2. The filling ratio was 33\% v/v based on the results of previous studies [28,29]. The packing rings were inserted in a closed 
7-mm stainless steel grid basket. The activated sludge was separated from the treated water in a $5 \mathrm{~L}$ gravity settler. A peristaltic pump (Masterflex, Gelsenkirchen, Germany) was used to recirculate the settled sludge into the bioreactors. The recirculation rate was set at $200 \%$ of the feed rate to prevent sludge from accumulating in the settlers. The synthetic PW was also fed into the bioreactor by a peristaltic pump (Masterflex). Aeration was provided with compressed air and injected to the system through a porous membrane at the bottom of the column (Jäger). Flowrates were measured using a rotameter (Analyt, Müllheim, Germany). Air input ranged between 120 and $960 \mathrm{~L} \cdot \mathrm{h}^{-1}$.

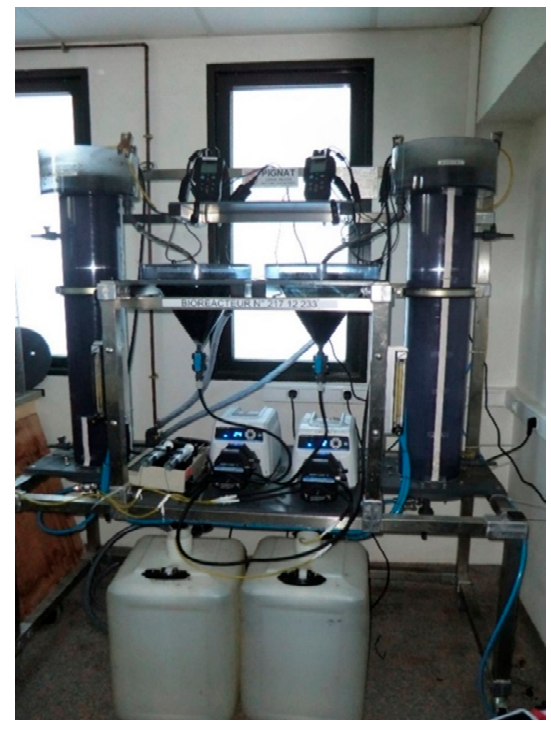

(a)

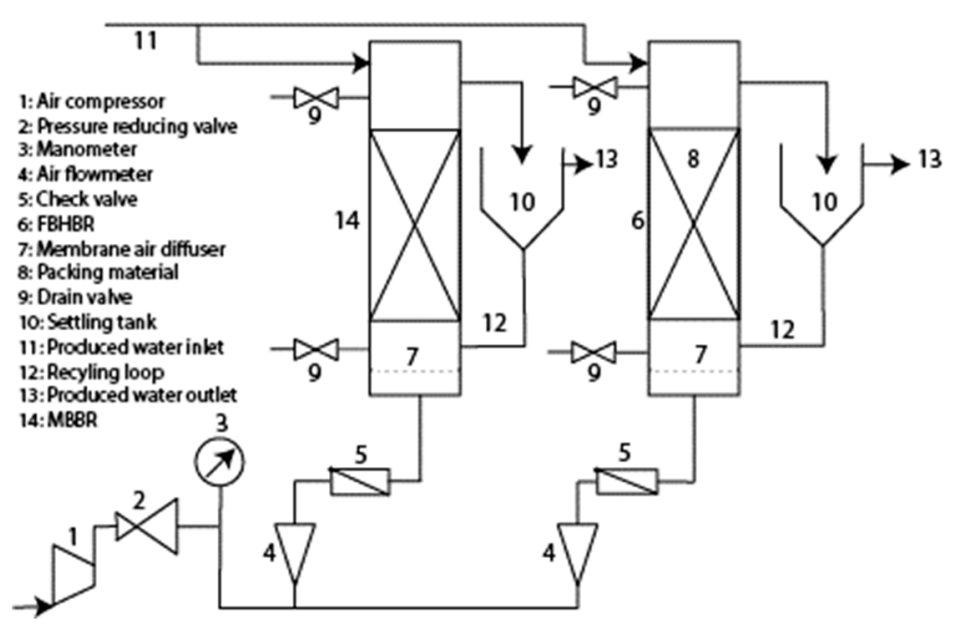

(b)

Figure 1. Laboratory pilots' plants (MBBR and FBHBR): (a) photograph and (b) schematic diagram of the experiemental setup.

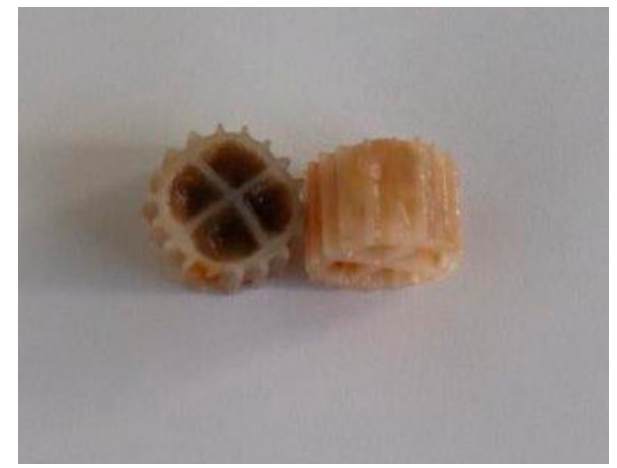

Figure 2. Photograph of AnoxKaldnes rings.

\subsection{Microbial Inoculum}

The inoculum was withdrawn from a municipal wastewater treatment plant, in the activated sludge recycling line (Aix en Provence, France). Initially, the amount of collected activated sludge was set into two identical plastic batch reactors under gentle stirring. $20 \mathrm{~L}$ of Clean AnoxKaldnes rings were inserted in the reactors to develop a biofilm for 30 days. During this biofilm growth period, the activated sludge was fed with sodium acetate, ammonium chloride and potassium dihydrogen phosphate while respecting a $\mathrm{C} / \mathrm{N} / \mathrm{P}$ ratio of $100 / 5 / 1$. The remaining sludge and colonized rings were equally put in the continuous bioreactor to configure a MBBR and a FBHBR. During the whole experiment, the sludge retention time was 20 days. 


\subsection{Composition of the Synthetic Produced Water}

A synthetic PW was used to perform the experiments. However, the concentration of targeted pollutants may be low to insure the viability of the biomass. Therefore, dissolved nutrients were added to the PW to set values of Chemical Oxygen Demand (COD), Total Nitrogen (TN) and Total Phosphorous (TP) at 1600, 20.6 and $4 \mathrm{mg} \cdot \mathrm{L}^{-1}$, respectively. A detailed composition of the synthetic PW is summarized in Table 1

Table 1. Composition of the synthetic produced water.

\begin{tabular}{cc}
\hline Compound & Concentration $\left.\mathbf{( m g} \cdot \mathbf{L}^{-\mathbf{1}}\right)$ \\
\hline COD (adjusted with ethanol, sodium acetate, urea and peptone) & 1600 \\
TOC & 379 \\
TN (from NH4Cl, urea and peptone) & 20.6 \\
TP (from KH2PO4) & 4 \\
Phenol & 12 \\
Toluene & 8 \\
o-Xylene & 1 \\
m-Xylene & 3 \\
Naphthalene & 0.2 \\
Phenanthrene & 0.05 \\
Benzo[a]pyrene & 0.0002 \\
\hline
\end{tabular}

The salinity (expressed as TDS concentration) was gradually increased throughout the experiment. TDS concentrations were set at $1.5 \mathrm{~g} \cdot \mathrm{L}^{-1}$ from day 1 to day $100,8 \mathrm{~g} \cdot \mathrm{L}^{-1}$ from day 101 to day 180 and $20 \mathrm{~g} \cdot \mathrm{L}^{-1}$ from day 181 to day 216 .

\subsection{Experimental Schedule}

The experiment was divided into four steps. Each step consisted in an increase in the TDS concentration. Three TDS concentrations were successively studied: 1.5, 8 and $20 \mathrm{~g} \cdot \mathrm{L}^{-1}$. The concentrations of pollutants were constant during the whole experimental period. The HRT was set at the constant value of $12 \mathrm{~h}$. The OLR based on the working volume (30 L in both MBBR and FBHBR) was $3.2 \mathrm{kgCOD} \cdot \mathrm{m}^{-3} \cdot \mathrm{d}^{-1}$. All these key parameters are summarized in Table 2.

Table 2. Bioreactors operation during the experiment.

\begin{tabular}{cccc}
\hline Phase & I & II & III \\
\hline Duration $($ days $)$ & $1-120$ & $121-180$ & $181-216$ \\
HRT $(\mathrm{h})$ & 12 & 12 & 12 \\
OLR $\left(\mathrm{kgCOD} \cdot \mathrm{m}^{-3} \cdot \mathrm{d}^{-1}\right)$ & 3.2 & 3.2 & 3.2 \\
Salinity $\left(\mathrm{g} \cdot \mathrm{L}^{-1}\right)$ & 1.5 & 8 & 20 \\
\hline
\end{tabular}

\subsection{Analytical Methods}

\subsubsection{Solids Concentration Measurements}

Standards methods were applied to measure both free TSS and VSS concentrations [40]. In both the MBBR and the FBHBR, the quantity of biofilm was assessed at each phase of the experimental period. The biofilm weight was determined using an experimental procedure described by Abtahi et al. [41].

\subsubsection{Physical-Chemical Parameters}

Dissolved oxygen (DO) concentrations, $\mathrm{pH}$ and temperature using oxygen electrodes (LDO10101, Hach, Loveland, CO, USA) and pH electrodes (PHC101, Hach, Loveland, CO, USA). It is also worth noting that all water samples were filtered using $0.45 \mu \mathrm{m}$ polyether sulfone filters before analysis. COD and phenol were analyzed using Hach DR6000 analytical kits and spectrophotometric measurements. BTEX (toluene, m-xylene and oxylene) were measured by mean of a standardized chromatographic method (Headspace 
GC/MS) [42]. PAHs (naphthalene, phenanthrene, benzo[a]pyrene) were measured by mean of gas chromatography coupled with mass spectrometry [43].

\subsubsection{Evaluation of Water Ecotoxicity}

Ecotoxicity tests were performed to evaluate the potential toxicity of both MBBR and FBHBR outlet waters. Samples were taken at the end of each step of the whole experimental period. The feed inlet and both MBBR and FBHBR outlet were tested. Standardized test used were the Microtox (Vibrio fischeri) acute toxicity test [44], the freshwater algae (Pseudokirchneriella subcapitata) acute toxicity test [45], the Daphnia magna acute toxicity test [46], and the Brachionus calyciflorus chronic toxicity test [47]. When the increase in salinity was not compatible with the freshwater microorganisms, marine ecological tests were chosen to measure the ecotoxicity of the treated water. These were the growth inhibition of a marine algae (Phaeodactylum tricornutum) test [48] and the acute lethal toxicity of marine crustacea (Artemia salina) test [49].

\subsubsection{Characterization of the Microbial Population}

The evolution of the microbial population in both the CAS reactor and FBHBR was investigated between the different key stages of the experiment: at the beginning of the acclimation and after the end of each step. The extraction and characterization procedure was described in a previous study [17].

\section{Results and Discussion}

\subsection{Evolution of Solids Concentrations}

The evolution of free TSS in both reactors are represented in Figure 3b. During the first step (day 1-100) of the bioreactors operation (TDS $=1.5 \mathrm{~g} \cdot \mathrm{L}^{-1}$ ), a large decrease is observed from days 1 to 30 (from $10.23 \mathrm{~g} \cdot \mathrm{L}^{-1}$ to $1.18 \mathrm{~g} \cdot \mathrm{L}^{-1}$ in the FBHBR and from $7.5 \mathrm{~g} \cdot \mathrm{L}^{-1}$ to $0.8 \mathrm{~g} \cdot \mathrm{L}^{-1}$ in the MBBR. This decrease, due to the acclimation of the biomass, is the result of the toxicity of the PW compounds which is lethal for some bacterial species composing the activated sludge that we used to seed our bioreactors at $t=0$. For instance, the analysis of the microbial population revealed differences between the inoculum and the population after the acclimation (disappearance of Planctomyces sp., Nitrospira sp., Dokdonella sp., Diaphorobacter sp. and a large part of unclassified species whereas Flavobacterium sp., Hydrogenophaga sp., and Dechloromonas sp. grew in all biomasses). Those observations will be further discussed in Section 3.4.

At the end of this first acclimation step, free TSS concentrations were $3.75 \mathrm{~g} \cdot \mathrm{L}^{-1}$ in the FBHBR and $2.94 \mathrm{~g} \cdot \mathrm{L}^{-1}$ in the MBBR. The second step started from day 101 to day 180, with a gradual increase of TDS concentration from $1.5 \mathrm{~g} \cdot \mathrm{L}^{-1}$ to $8 \mathrm{~g} \cdot \mathrm{L}^{-1}$ (day 101-145). At the end of the second step (TDS $=8 \mathrm{~g} \cdot \mathrm{L}^{-1}$ ), the free TSS concentrations were $2.39 \mathrm{~g} \cdot \mathrm{L}^{-1}$ and $2.19 \mathrm{~g} \cdot \mathrm{L}^{-1}$ in the FBHBR and the MBBR, respectively. This represents a decrease by $56 \%$ in the FBHBR and by $34 \%$ in the MBBR. An increase in TSS concentrations by $123 \%$ in the FBHBR and by $140 \%$ in the MBBR was observed during the third step, from day 181 to day 216 (TDS $=20 \mathrm{~g} \cdot \mathrm{L}^{-1}$ ). At the end of the process operation, free TSS concentrations were $5.33 \mathrm{~g} \cdot \mathrm{L}^{-1}$ and $5.26 \mathrm{~g} \cdot \mathrm{L}^{-1}$ in the FBHBR and the MBBR, respectively. The evolution of the free TSS concentrations revealed that there seems to be no significant differences between the FBHBR and the MBBR based on this parameter.

The evolution of free VSS concentrations in both reactors are represented in Figure 3c. The free VSS concentrations followed the same trend as the free TSS concentrations in both reactors. At the end of step I, VSS concentrations were $3.23 \mathrm{~g} \cdot \mathrm{L}^{-1}$ in the FBHBR and $2.56 \mathrm{~g} \cdot \mathrm{L}^{-1}$ in the MBBR. At the end of step II, free VSS concentrations decreased to $0.69 \mathrm{~g} \cdot \mathrm{L}^{-1}$ in the FBHBR and $1.16 \mathrm{~g} \cdot \mathrm{L}^{-1}$ in the MBBR. This represents a decrease by $79 \%$ in the FBHBR and by $55 \%$ in the MBBR. At the end of the bioreactors operation, free VSS concentrations increased by $333 \%$ to $2.99 \mathrm{~g} \cdot \mathrm{L}^{-1}$ in the FBHBR and by $237 \%$ to $3.91 \mathrm{~g} \cdot \mathrm{L}^{-1}$ in the MBBR. From the beginning of the process operation to day 127 , there were no significant differences between the FBHBR and the MBBR concerning the free VSS concentrations. 
When the TDS was increased to $5 \mathrm{~g} \cdot \mathrm{L}^{-1}$, free VSS concentrations appeared to be bigger in the MBBR than in the FBHBR.

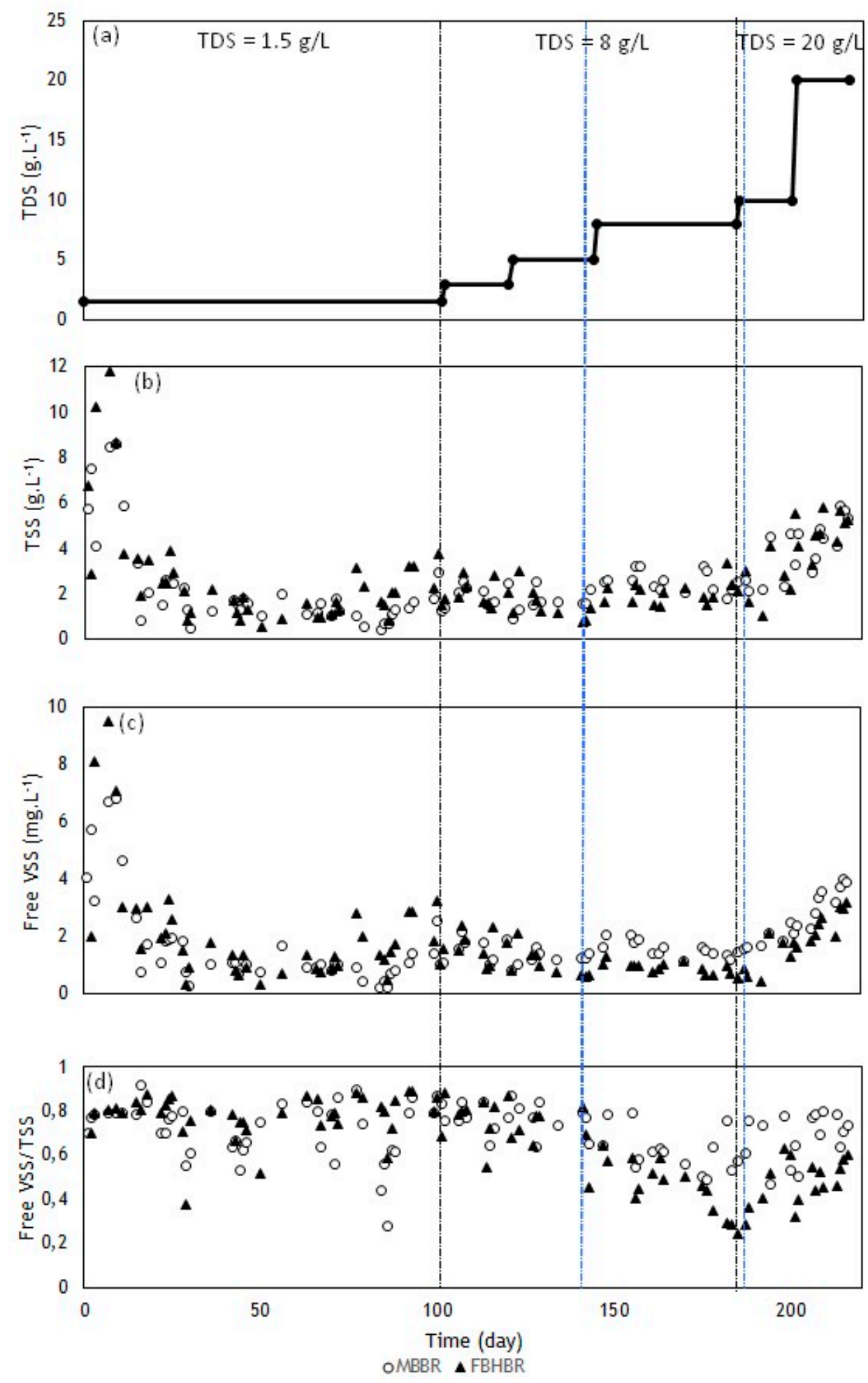

Figure 3. Evolution of solids concentrations in both MBBR and FBHBR during the experiment: TDS concentration (a), free TSS concentration (b), free VSS concentration (c) and free VSS/TSS ratio (d).

To better understand the evolution of solids concentrations, values of free VSS/TSS ratios are plotted against time in Figure 3d. During the first step (TDS $=1.5 \mathrm{~g} \cdot \mathrm{L}^{-1}$ ), free VSS/TSS ratios were high, reaching an average value of 0.8 in the FBHBR and 0.8 in 
the MBBR. These values are typical of biomasses grown in synthetic PWs and reflect the absence of accumulation of inert material in both reactors [24]. As a comparison, Sambusiti et al. (2020) reported VSS/TSS ratios around $92 \%$ in a submerged MBR treating a synthetic PW. From the step II, free VSS/TSS ratios began to decrease. At the end of step II, VSS/TSS ratios were 0.29 in the FBHBR and 0.53 in the MBBR. At the end of process operation, an increase of free VSS/TSS ratios was observed, up to 0.6 in the FBHBR and 0.73 in the MBBR. Nonvisible in the evolution of free TSS and free VSS concentrations, the evolution of free VSS/TSS ratios seems to reflect the perturbations caused by the different increases in TDS concentrations. The decrease in VSS/TSS ratio in both bioreactors reflect the loss of bacteria with the increase of TDS concentrations. In the literature, salinity has been reported as a parameter that strongly affects biological treatments. Previous studies reported that salinity starts to affect biological treatment operation at chloride concentration above $5-8 \mathrm{~g} \cdot \mathrm{L}^{-1}[30,50]$. The increase in salinity is also responsible for a decrease in VSS concentrations and an increase in TSS concentrations. This is observed in both bioreactors after day 142. The phenomenon that could explain this increase is an accumulation of salts inside the suspended sludge. Nevertheless, the VSS/TSS ratio increased again at day 176 in the MBBR and day 188 in the FBHBR. The increase of the ratio at the end of bioreactors operations seems to show an acclimation of the biomass to the saline wastewater. The combined effects of the increase in biomass and the accumulation of inorganic solids are so responsible for the increase in free TSS concentrations. At the end of the process operation, the Figure 3d clearly shows that the VSS/TSS ratios are higher in the MBBR than in the FBHBR. Indeed, the average ratio is 0.67 in the MBBR and 0.47 in the FBHBR. This could be explained by the fact that under the same loading rate, the suspended sludge production is higher in the MBBR. In the FBHBR, the packing material offers a bigger specific area than in the MBBR. Therefore, the organic loading required for the biofilm growth is bigger in the FBHBR than in the MBBR. This should lead to a bigger biofilm extent in the FBHBR. It is also worth noting that we measured only the free VSS. The biofilm in both bioreactors also contains a part of volatile solids. Hence, as it will be discussed below, the biofilm has a bigger extent in the FBHBR than in the MBBR. This also explains why free VSS concentration are lower in the FBHBR at the end of the process operation. Indeed, the large part of the bacteria are present in the biofilm rather than in the free sludge.

The presence of the packing material in both MBBR and FBHBR allowed the biofilm to develop. In the MBBR, the biofilm grew on the internal surface of the Kaldnes rings. In the FBHBR, the biofilm grew in the internal and external surface of the Kaldnes rings. There is no shear stress imposed to the external ring surface in the FBHBR, which explain the larger development of the biofilm.

Results of biofilm quantification during the process operation are shown in Figure 4. When the salinity was $1.5 \mathrm{~g} \cdot \mathrm{L}^{-1}$ (step I), biofilm weights were $4.52 \mathrm{mg}$ per carrier and $6.59 \mathrm{mg}$ per carrier in the MBBR and FBHBR, respectively. A decrease in biofilm weights was observed when the salinity increased to $8 \mathrm{~g} \cdot \mathrm{L}^{-1}$, especially in the MBBR $(1.37 \mathrm{mg}$ per carrier in the MBBR and $6.1 \mathrm{mg}$ per carrier in the FBHBR). Finally, biofilm weights increased again at a salinity of $20 \mathrm{~g} \cdot \mathrm{L}^{-1}$, reaching $3.64 \mathrm{mg}$ per carrier in the MBBR and $12.69 \mathrm{mg}$ per carrier in the FBHBR. Both bioreactors were filled with $10 \mathrm{~L}$ of carriers which corresponds to approximately 10,800 rings. Based on this number, the total biofilm weight should be $39.3 \mathrm{~g}$ for the MBBR and $137.1 \mathrm{~g}$ for the FBHBR. This suggests a significant biofilm development in the FBHBR compared to the MBBR and that the operational conditions are still satisfactory for biofilm growth. Finally, the biofilm weight is 3.5 times higher in the FBHBR than in the MBBR, which is consistent with the development of the biofilm on the external surface of the packing material. The presence of the biofilm brings interesting advantages such as a better resistance to loading shocks and toxic compounds which should be beneficial at higher salinity. 


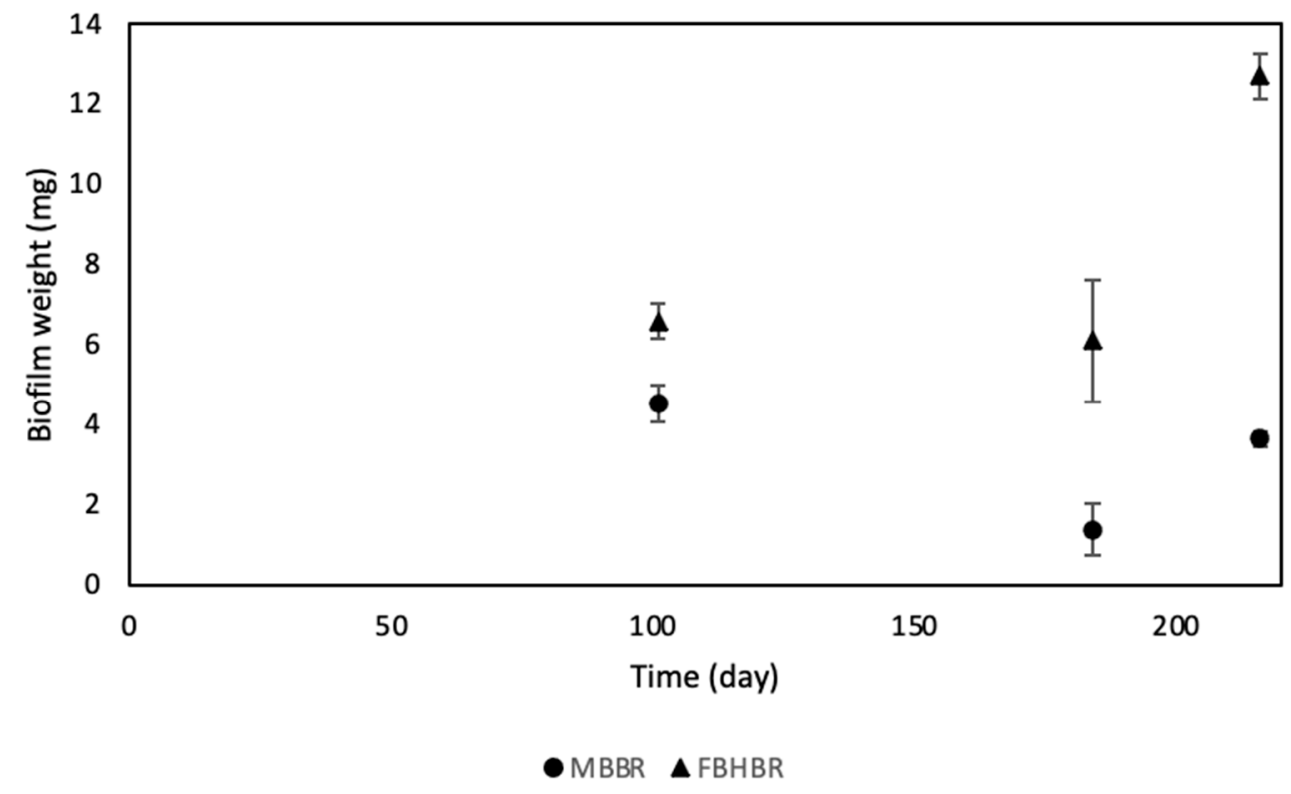

Figure 4. Evolution of biofilm weight in both MBBR and FBHBR during the process operation.

\subsection{Removal of Pollutants}

\subsubsection{Chemical Oxygen Demand Removal}

The time evolution of COD removal efficiencies in both reactors is represented in Figure 5b. For better understanding, the increase in the TDS concentration presented in Figure $3 \mathrm{a}$ is plotted again in Figure 5a. Large fluctuations of COD removal efficiencies values were observed during the step I of bioreactors operation. These fluctuations are attributed to the acclimation of the activated sludge biomass to the new influent. At the end of the first step, COD removal efficiencies reached $80 \%$ for the FBHBR and $74 \%$ for the MBBR. During the step II, COD removal efficiencies increased again by $13 \%$ in the FBHBR and by $22 \%$ in the MBBR, reaching values above $90 \%$. The values remained high during the step III. At the end of the bioreactors operation, COD removal efficiencies were $93 \%$ for the FBHBR and $85 \%$ for the MBBR. These values reflect the high biodegradability abilities of the synthetic PW in both reactors. Furthermore, the evolution of the COD removal efficiencies shows that, once the biomass has been properly acclimated to the presence of salt (end of step I), the TDS concentration does not affect the treatment efficiency in both reactors. In the literature, there are few studies relating the treatment of PW with salinity variations. Our findings here are consistent with some studies reporting high removal efficiencies with synthetic PW in the presence of high TDS concentrations. As an example, Sharghi et al. (2016) reported COD removal efficiencies from 94.6 to $81.6 \%$ with salinity increasing from 100 to $250 \mathrm{~g} \cdot \mathrm{L}^{-1}$ in a submerged membrane bioreactors [18]. Their OLR was $2.6 \mathrm{kgCOD} \cdot \mathrm{m}^{-3} \cdot \mathrm{d}^{-1}$ with an HRT of $24 \mathrm{~h}$. Their results were also obtained with a consortium of isolated microorganisms. Compared to these results, COD removal efficiencies obtained in this study in the MBBR and the FBHBR seem to indicate that high removal efficiencies can be achieved at shorter HRT and with acclimated microorganisms but smaller TDS concentrations. 


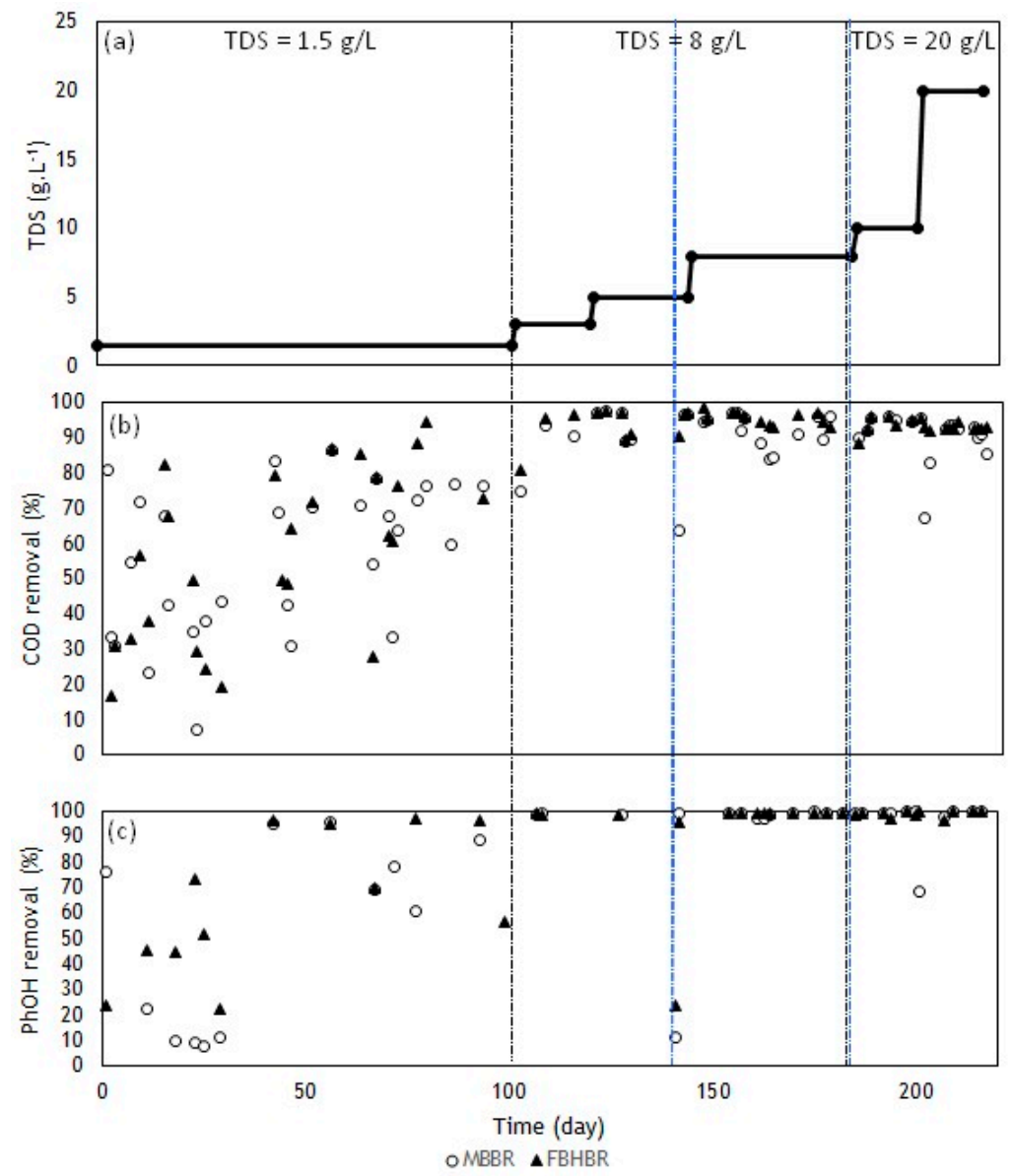

Figure 5. Evolution of COD removal efficiency and phenol removal efficiency in both MBBR and FBHBR during the experiment: TDS concentration (a), COD removal (b) and phenol removal (c).

\subsubsection{Pollutant Removal Performance}

Phenol removal efficiencies quickly reached satisfying levels (more than $96 \%$ in both bioreactors at day 42. During step II and step III, phenol removal efficiencies remained high, with values above $95 \%$ in both bioreactors. No significant differences were observed between both bioreactors. This suggests that a moderate salinity (TDS concentration up to $20 \mathrm{~g} \cdot \mathrm{L}^{-1}$ ) does not affect phenol removal efficiencies. Furthermore, both configurations proved their ability to remove this compound.

Removal efficiencies of toluene, o-xylene and m-xylene in both MBBR and FBHBR over $99 \%$ were observed at each step of the operation of the bioreactor. This suggests that the increase of TDS concentration does not affect the treatment efficiency of volatile organic compounds. The high volatility of these compounds combined with the aeration are suggesting that the main removal mechanism of these compounds from the PW is achieved by volatilization and/or adsorption [51].

Removal efficiencies of naphthalene, phenanthrene and benzo[a]pyrene were also assessed in both bioreactors. Here again, high removal efficiencies are observed for naphthalene and phenanthrene (over 99\%). Concerning benzo[a]pyrene, a removal efficiency of $93 \%$ was observed in both bioreactors at the end of the first step. The removal efficiency then increased to $97 \%$ and $98 \%$ at the end of the second and third steps, respectively. This was due to different inlet concentrations of benzo[a]pyrene measured during the sample analyses after each step (outlet concentrations were below the quantification limit for both outlets at each step). Nevertheless, removal efficiencies for benzo[a]pyrene (above $90 \%$ ), as well as for naphthalene and phenanthrene suggest that TDS concentrations up to $20 \mathrm{~g} \cdot \mathrm{L}^{-1}$ do not significantly affect the efficiency of both MBBR and FBHBR for removing PAHs. 


\subsection{Ecotoxicity Assessments}

Water toxicity was assessed at the end of step I and step II. As TDS concentration may interfere in the toxicity of freshwater microorganisms, saline microorganisms were preferred to freshwater microorganisms for the toxicity assessment at the end of step II. Results of toxicity assessments for the first step (TDS $=1.5 \mathrm{~g} \cdot \mathrm{L}^{-1}$ ) are summarized in Table 3. Results are here expressed as EC50 (\%), meaning a minimum of \% EC50 indicates a high toxicity of the sample to the tested microorganism, whereas a maximum of $\%$ EC 50 indicates an absence of toxicity of the sample to the tested microorganism. Here, values of $\%$ EC50 shows that the inlet water was highly toxic to Daphnia magna and moderately toxic to Brachionus calyciflorus, Pseudokirchneriella subcapitata and Vibrio fischeri. After treatment, an absence of toxicity is observed for all microorganisms. This absence of toxicity was due to the elimination of pollutants in both bioreactors.

Table 3. Ecotoxicity measurements of inlet water (TDS $\left.=1.5 \mathrm{~g} \cdot \mathrm{L}^{-1}\right)$ and outlet water $(\mathrm{MBBR}$ and FBHBR) expressed as EC50 (\%) (NT refers as Nont-Toxic).

\begin{tabular}{cccc}
\hline Microorganism & \multicolumn{3}{c}{ Tested Water } \\
\hline & Inlet PW & Outlet MBBR & Outlet FBHBR \\
\hline Daphnia magna & 1.6 & NT & NT \\
\hline Brachionus calyciflorus (rotifer) & 22.7 & $>90$ & $>90$ \\
\hline $\begin{array}{c}\text { Pseudokirchneriella subcapitata } \\
\text { (freshwater algae) }\end{array}$ & 35 & $>90$ & $>90$ \\
\hline Vibrio fischeri (microtox test) & 29.9 & NT & NT \\
\hline
\end{tabular}

For the step II (TDS $\left.=8 \mathrm{~g} \cdot \mathrm{L}^{-1}\right)$, the toxicity of water samples was assessed on Vibrio fischeri, Phaeodactylum tricornutum (marine algae) and Artemia salina (crustaceans). Results are presented in Table 4 . Results show here that the inlet water was moderately toxic to all three microorganisms. An absence of toxicity was observed for Vibrio fischeri and Artemia salina in the outlet water of both MBBR and FBHBR. However, a moderate toxicity is observed for Phaeodactylum tricornutum (\% EC50 of 38.4 and 60.6 in the MBBR and FBHBR, respectively). These values coupled to the fact that all pollutants were efficiently removed from the PW suggests that the observed toxicity was not due to the pollutant but to another parameter. We suggest that in this case, at a TDS concentration of $8 \mathrm{~g} \cdot \mathrm{L}^{-1}$, the salt concentration may be too low to use a marine algae for toxicity assessment purposes.

Table 4. Ecotoxicity measurements of inlet water $\left(T D S=8 \mathrm{~g} \cdot \mathrm{L}^{-1}\right)$ and outlet water (MBBR and FBHBR) expressed as EC50 (\%) (NT refers as Non-Toxic).

\begin{tabular}{cccc}
\hline Microorganism & \multicolumn{3}{c}{ Tested Water } \\
\hline & Inlet PW & Outlet MBBR & Outlet FBHBR \\
\hline Vibrio fischeri (microtox test) & 48.5 & $\mathrm{NT}$ & $\mathrm{NT}$ \\
Phaeodactylum tricornutum & 29.7 & 38.4 & 60.6 \\
(marine algae) & 50.7 & $\mathrm{NT}$ & $\mathrm{NT}$ \\
Artemia salina (crustaceans) & & & \\
\hline
\end{tabular}

\subsection{Assessment of Bacterial Populations}

\subsubsection{Evolution of Bacterial Diversity}

The bacterial population was assessed along the MBBR and FBHBR operation. 13 samples were analyzed: the inoculum, the MBBR biofilm and MBBR free sludge at the end of each steps under TDS concentrations of $1.5 \mathrm{~g} \cdot \mathrm{L}^{-1}, 8 \mathrm{~g} \cdot \mathrm{L}^{-1}$ and $20 \mathrm{~g} \cdot \mathrm{L}^{-1}$, and the FBHBR biofilm and FBHBR free sludge at the end of each steps under TDS concentrations of $1.5 \mathrm{~g} \cdot \mathrm{L}^{-1}, 8 \mathrm{~g} \cdot \mathrm{L}^{-1}$ and $20 \mathrm{~g} \cdot \mathrm{L}^{-1}$. The inoculum was sampled at the beginning of the bioreactors operation (day 0 ). Samples at TDS concentration of $1.5 \mathrm{~g} \cdot \mathrm{L}^{-1}$ were sampled on 
day 101, samples at TDS concentration of $8 \mathrm{~g} \cdot \mathrm{L}^{-1}$ were sampled on day 183 and samples at TDS concentration of $20 \mathrm{~g} \cdot \mathrm{L}^{-1}$ were sampled on day 216.

The number of OTU of each sample are represented in Figure $6 \mathrm{~b}$. In the inoculum, the number of OTU was 915. In the MBBR, the number of OTU was 437 for the biofilm and 301 for the free sludge at a TDS concentration of $1.5 \mathrm{~g} \cdot \mathrm{L}^{-1}$. When the TDS concentration was set to $8 \mathrm{~g} \cdot \mathrm{L}^{-1}$, the number of OTU was 473 for the biofilm and 225 for the free sludge. In the FBHBR, the number of OTU was 509 for the biofilm and 387 for the free sludge. When the concentration was set to $8 \mathrm{~g} \cdot \mathrm{L}^{-1}$, the number of OTU decreased to 283 for the biofilm and 300 for the free sludge. At the end of the bioreactors operation, i.e., at a TDS concentration of $20 \mathrm{~g} \cdot \mathrm{L}^{-1}$, the number of OTU were 230 and 163 in the MBBR biofilm and MBBR free sludge, respectively. In the FBHBR biofilm and FBHBR free sludge, the number of OTU was 239 and 178, respectively. These values suggest that the diversity of species decreased during the bioreactors operation. However, the decrease in the number of OTU along the time of operation of bioreactors is consistent the further increase of TDS concentration. There is a tendency of higher number of OTU in the biofilm in both bioreactors compared to the free sludge. This suggests that the diversity of species was moderately higher in the biofilm than in the free sludge.

Figure 6a represents the evolution of the Shannon-Weaver index in all biomasses during the bioreactors operation. The index of the inoculum was 5.56, suggesting a high diversity of species. A significant decrease of the indices was observed during the bioreactors operation. In the MBBR, the index was 3.83 in the biofilm and 3.5 for the free sludge at a TDS concentration of $1.5 \mathrm{~g} \cdot \mathrm{L}^{-1}$. When the TDS concentration was set up to $8 \mathrm{~g} \cdot \mathrm{L}^{-1}$, the Shannon-Weaver index decreased to 3.61 for the biofilm and 2.90 for the free sludge. In the FBHBR, the index was 3.55 for the biofilm and 3.2 for the free sludge at a TDS concentration of $1.5 \mathrm{~g} \cdot \mathrm{L}^{-1}$. When the TDS concentration was set up to $8 \mathrm{~g} \cdot \mathrm{L}^{-1}$, the index decreased to 2.94 for the biofilm and 3.1 for the free sludge. Finally, at the end of the bioreactors operation, Shannon-Weaver indices were 2.86 and 2.99 in MBBR biofilm and MBBR free sludge. In the FBHBR biofilm and FBHBR free sludge, Shannon-Weaver indices were 3.29 and 3.03. These values lead to the same conclusion than the evolution of the number of OTU, i.e., a significant speciation of species in both reactors with time as TDS concentrations increased. The increase in salinity is probably lethal to some bacteria communities and explain the decrease in the Shannon-Weaver index.

The evolution of the Simpson reciprocal index of all biomasses is presented in Figure 6c. The Simpson reciprocal index of the inoculum was 109.6. Here again, a significant decrease of the Simpson reciprocal index is observed for all biomasses during the bioreactors operation. In the MBBR, the Simpson reciprocal indices were 16.4 for the biofilm and 16.1 for the free sludge at a TDS concentration of $1.5 \mathrm{~g} \cdot \mathrm{L}^{-1}$. When the TDS concentration was set up to $8 \mathrm{~g} \cdot \mathrm{L}^{-1}$, Simpson reciprocal indices were 9.18 for the biofilm and 9.80 for the free sludge. In the FBHBR, the Simpson reciprocal indices were 8.7 in the biofilm and 10.5 in the free sludge at a TDS concentration of $1.5 \mathrm{~g} \cdot \mathrm{L}^{-1}$; When the TDS concentration was set up to $8 \mathrm{~g} \cdot \mathrm{L}^{-1}$, the indices were 7.21 in the biofilm and 10 in the free sludge. Finally, at the end of bioreactors operation, Simpson reciprocal indices were 5.69 and 10.7 in the MBBR biofilm and MBBR free sludge, respectively. In the FBHBR biofilm and FBHBR free sludge, Simpson reciprocal indices were 13.87 and 11.1, respectively.

The number of OTU, the Shannon Weaver index and the Simpson reciprocal index all indicate that the microbial species diversity is significantly reduced over the time and in both MBBR and FBHBR, as the TDS concentration is slowly increased from 1.5 to $20 \mathrm{~g} \cdot \mathrm{L}^{-1}$. This result is consistent with the fact that the increase in the TDS concentration is probably lethal to some bacterial species. Thus, a specialization appeared in both reactors, i.e., some bacterial species became more predominant in both MBBR and FBHBR. Even if the sludge retention time is not a limiting factor for biomass development in the biofilm, it appears that the PW composition has more influence on the bacterial development. Concerning the difference between the biofilm diversity and the free sludge diversity, the same conclusions as in the previous study are made here [17]. Indeed, all the diversity indices seem to 
indicate that the diversity is bigger in the biofilm than in the free sludge. Lastly, the diversity of species is slightly higher in the MBBR than in the FBHBR.

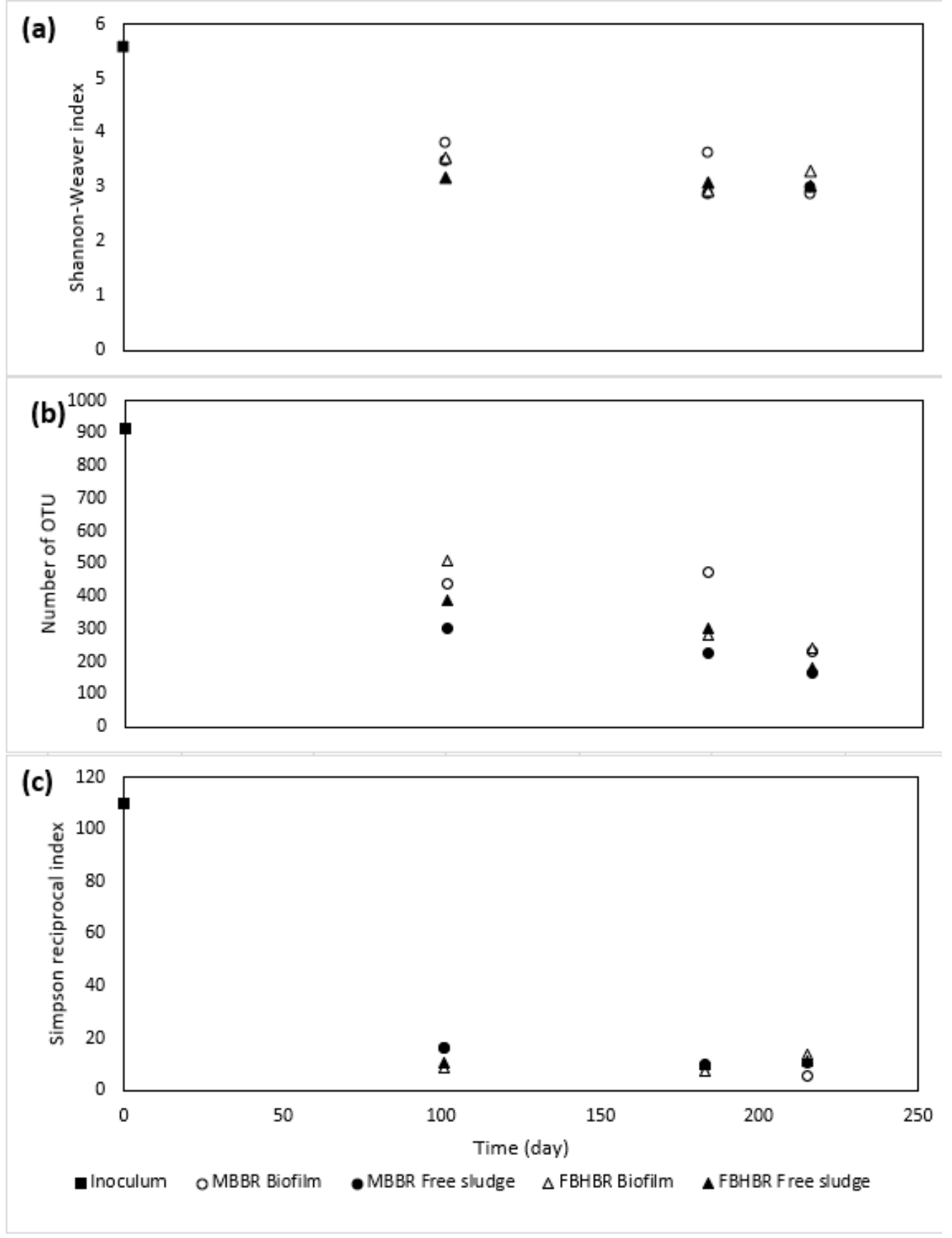

Figure 6. Evolution of bacterial diversity indices in both MBBR and FBHBR: Shannon Weaver index (a), number of OTU (b) and Simspon reciprocal index (c).

\subsubsection{Bacterial Population at TDS $=1.5 \mathrm{~g} \cdot \mathrm{L}^{-1}$}

Figure 7 shows the results of $16 \mathrm{~S}$ rRNA analysis of the bacterial communities at the genus level in the MBBR and the FBHBR when the TDS concentration was set to $1.5 \mathrm{~g} \cdot \mathrm{L}^{-1}$. The represented sequences only represent a minimum of $1 \%$ of their total sequences. The percentage of unclassified genus in the inoculum was surprisingly high (53.6\%). In the MBBR, a similarity is observed between the biofilm and the free sludge. 
In the MBBR biofilm, four species were dominants (corresponding to $41 \%$ of the total sequences): Dechloromonas sp., Flavobacterium sp., Mycoplana sp. and Zooglea sp. In the MBBR free sludge, four species were also dominant: Dechloromonas sp., Hydrogenophaga sp., Flavobacterium sp. and Mycoplana sp. (corresponding to $47 \%$ of the total sequences). In the In the FBHBR biofilm, three dominant species were found: Dechloromonas sp., Hydrogenophaga sp. and Flavobacterium sp. (corresponding to 53\% of the total sequences). In the FBHBR free sludge, five species were found dominants: Dechloromonas sp., Hydrogenophaga sp., Flavobacterium sp., Thiothrix sp. and Emticicia sp. (corresponding to $69 \%$ of the total sequences).

It is interesting to see that the most abundant species are Dechloromonas sp., $\mathrm{Hy}$ drogenophaga sp. and flavobacterium sp. In the literature, Dechloromonas sp were found to be able to degrade benzene, toluene, ethylbenzene and xylene [52]. This seems to indicate an acclimation of microorganisms to the PW influent.

\subsubsection{Bacterial Population at TDS $=8 \mathrm{~g} \cdot \mathrm{L}^{-1}$}

The assessment of bacterial population at the genus level in the MBBR biofilm and free sludge as well as in the FBHBR biofilm and free sludge under a TDS concentration of 8 g. $\mathrm{L}^{-1}$ are shown in Figure 8. From this second assessment, there were 57\%, 60\%, 48\% and $59 \%$ of unclassified genus in the MBBR biofilm, MBBR free sludge, FBHBR biofilm and FBHBR free sludge, respectively.

Some genus already present under a TDS concentration of $1.5 \mathrm{~g} \cdot \mathrm{L}^{-1}$ were found again in this second sequencing: Hydrogenophaga sp. in all biomasses, Thiothrix sp. in MBBR and FBHBR biofilm, Flavobacterium sp. in MBBR and FBHBR free sludge, Caulobacter sp. in FBHBR biofilm, Planctomyces sp. in FBHBR free sludge and Treponema sp. in MBBR biofilm.

With respect to the first sequencing, some gena developed further when the TDS concentration increased to $8 \mathrm{~g} \cdot \mathrm{L}^{-1}$ : Lewinella sp. and Pedobacter sp. in the MBBR and FBHBR free sludge, Nannocystis sp. in MBBR and FBHBR biofilm, Novosphingobium sp. and Sphingomonadales sp. in FBHBR free sludge, Haliscomenobacter sp. in FBHBR biofilm, $A 4 b \mathrm{sp}$. and Mb2424 sp. in MBBR biofilm. The most preponderant new genus were Lewinella sp. and Pedobacter sp.

The proportion of Lewinella sp. were 15\% in MBBR free sludge and $8 \%$ in FBHBR free sludge. Lewin (1970) originally described three novel marine species as Herpetosiphon sp. [53]. Those strains were later sequenced and related to the genus Lewinella [54]. Lewinella sp. are marine bacteria and originate from seawater. In the literature, there are only two articles relating the genus Lewinella to the degradation of hydrocarbon compounds $[55,56]$.

\subsubsection{Bacterial Population at TDS $=20 \mathrm{~g} \cdot \mathrm{L}^{-1}$}

The last DNA sequencing were performed at the end of the experiment at a TDS concentration of $20 \mathrm{~g} \cdot \mathrm{L}^{-1}$. Results of the sequencing are represented in Figure 9. In this sequencing, there were $80 \%, 77 \%, 74 \%, 72 \%$ of unclassified genus in the MBBR biofilm, MBBR free sludge, FBHBR biofilm and FBHBR free sludge, respectively.

There were two gena common to all tested samples, Hydrogenophaga sp. and Cytophagales sp. with abundances ranging from 4 to $12 \%$. Lewinella sp. were found abundant at $4 \%$ only in MBBR free sludge. In the FBHBR biofilm, the genus Fusibacter is found abundant at $5.1 \%$. 


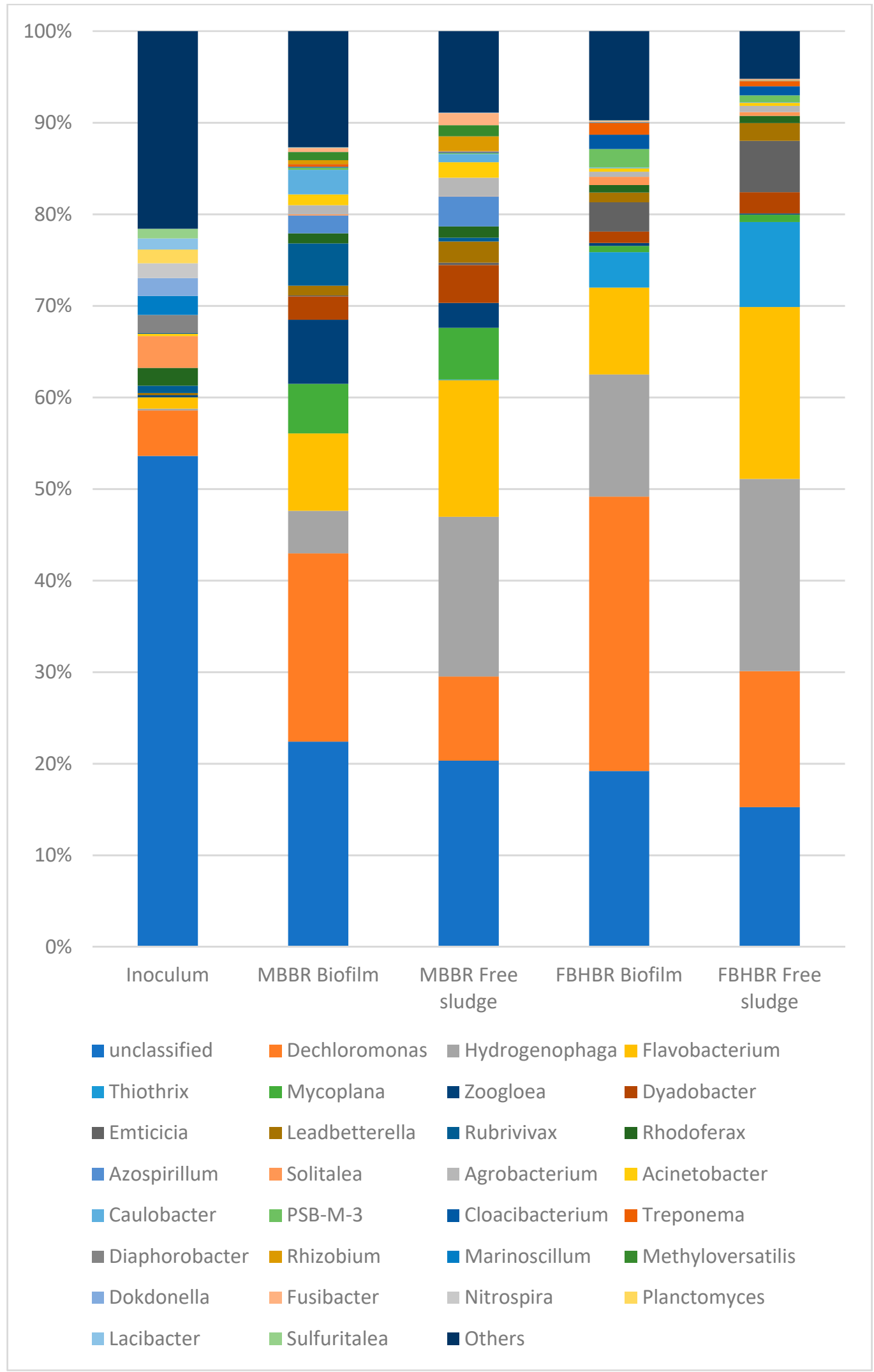

Figure 7. Bacterial assessment at the genus level in the MBBR and the FBHBR at TDS $=1.5 \mathrm{~g} \cdot \mathrm{L}^{-1}$. 


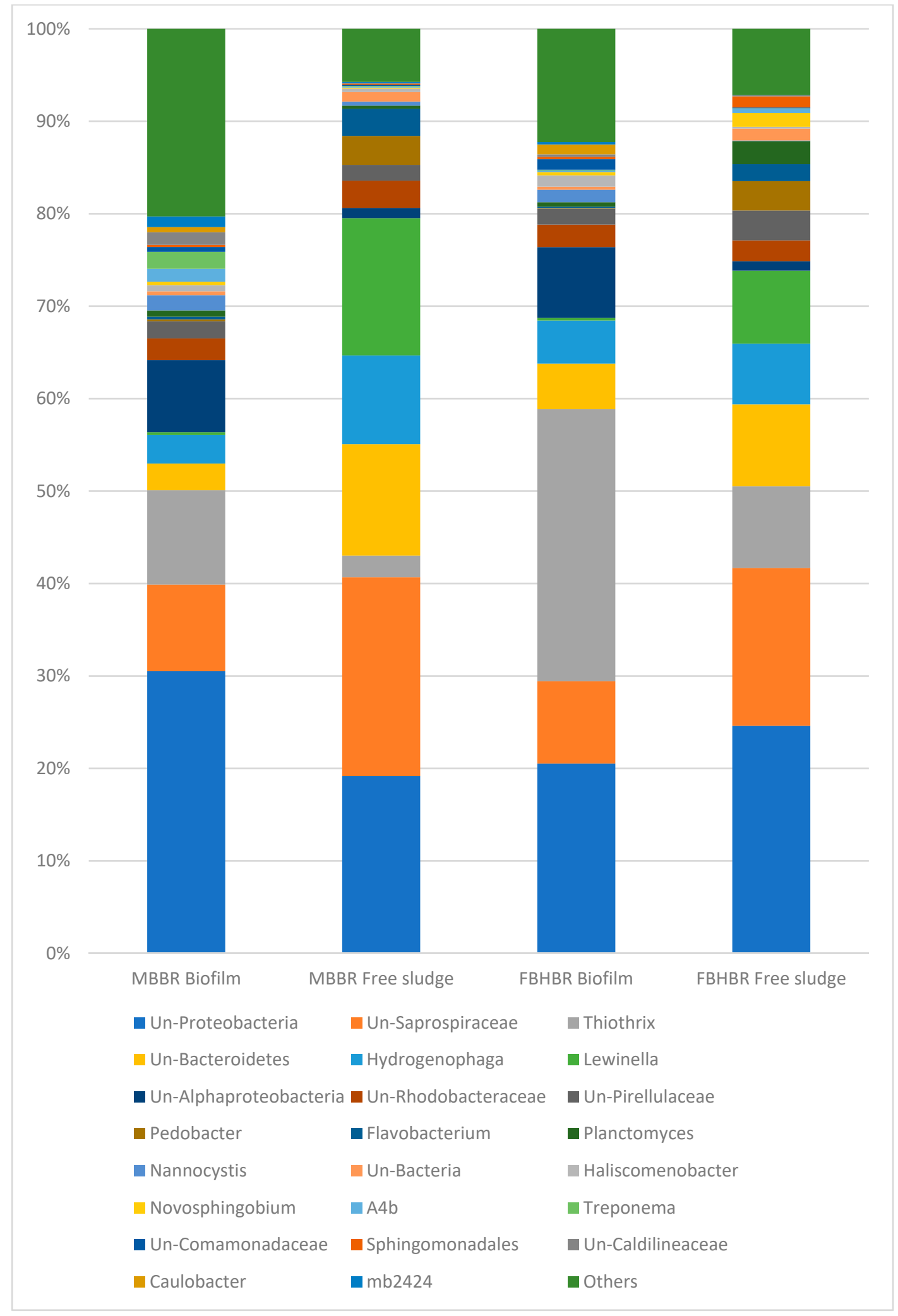

Figure 8. Bacterial assessment at the genus level in the MBBR and FBHBR at TDS $=8 \mathrm{~g} \cdot \mathrm{L}^{-1}$. 


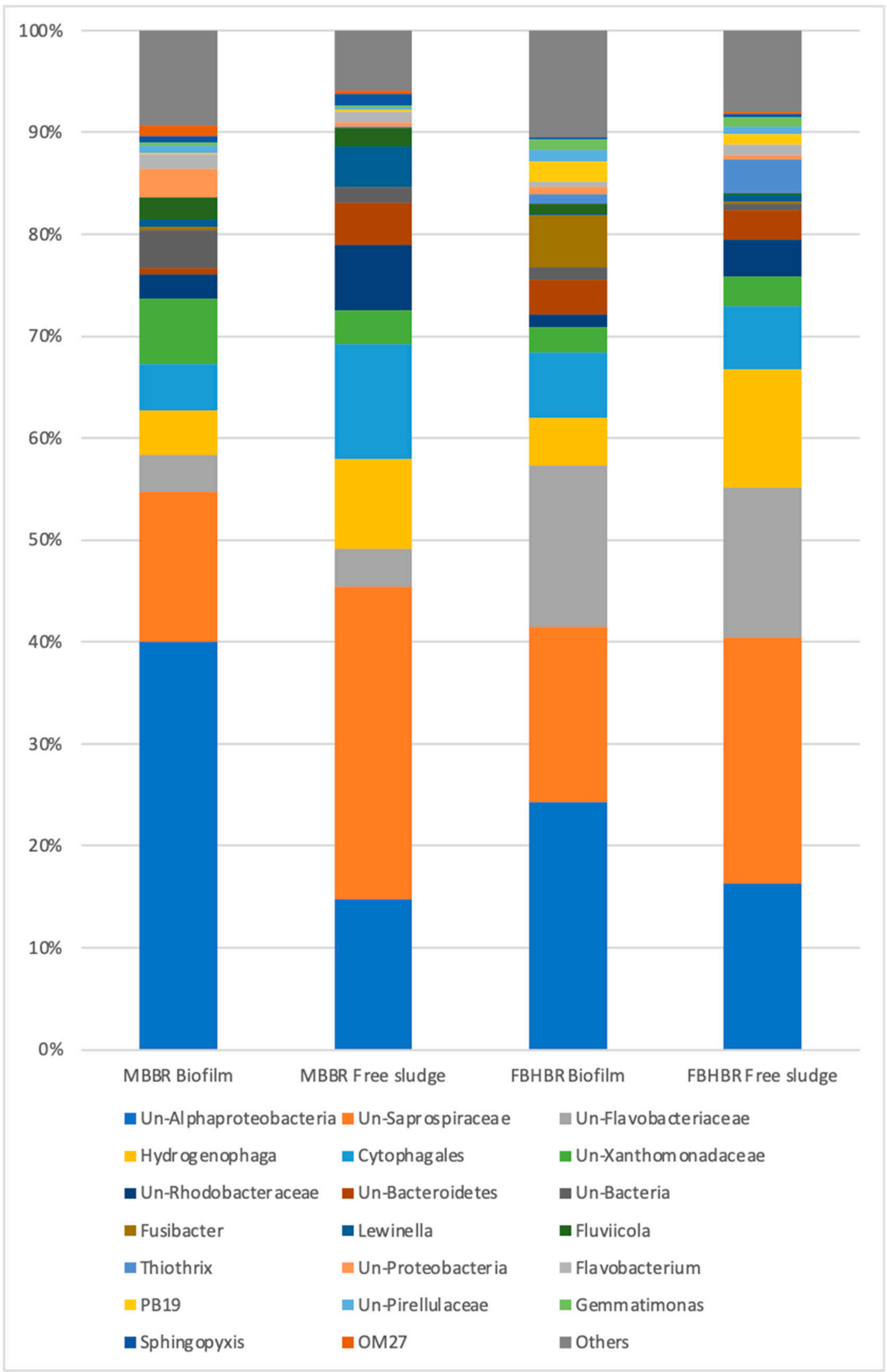

Figure 9. Bacterial assessment at the genus level in the MBBR and the FBHBR at TDS $=20 \mathrm{~g} \cdot \mathrm{L}^{-1}$ (Un stands for unclassified). 


\section{Conclusions}

This experimental study dealt with the influence of the increase in TDS concentration on treatment performances of a synthetic PW using two types of hybrid bioreactors, namely a MBBR and a FBHBR. The main conclusions obtained are:

- Both bioreactors exhibited an increase in TSS concentrations, once the acclimation phase was over, with the increase in TDS concentrations. At the same time, the free VSS/TSS ratio tended to decrease in both bioreactors, which suggests an accumulation of inorganic solids in the free suspended sludge.

- Both bioreactors were proved to be efficient to remove the COD from the influent as well as VOCs and PAHs. An absence of toxicity was noticed in the outlet water performing tests with different microorganisms.

- A decrease in the bacterial diversity indices was observed with respect to the inoculum, leading to the predominance of a lower number of bacterial species. Despite a large part of unclassified gena, some gena, such as Lewinella sp. seem to indicate a logical shift of the bacterial community from freshwater bacteria towards saline bacteria.

In future work, increasing the TDS concentration to higher level will be of major importance to reach more realistic of real produced water treatment.

Author Contributions: Conceptualization, N.L. (Nicolas Lusinier); methodology, N.L. (Nicolas Lusinier), I.S. and N.R.; writing — original draft preparation, N.L. (Nicolas Lusinier); writing-review and editing, N.L. (Nicolas Lusinier), I.S. and C.S.; supervision, I.S., C.S., M.J., N.L. (Nicolas Lesage). and N.R. All authors have read and agreed to the published version of the manuscript.

Funding: This research received funding from Total SA and financial administration was managed by Protisvalor, Aix-Marseille Université under the contract CR2222RCTOTD0.

Institutional Review Board Statement: Not Applicable.

Informed Consent Statement: Not applicable.

Data Availability Statement: All authors ensure that data shared are in accordance with consent provided by participants on the use of confidential data.

Conflicts of Interest: The authors declare no conflict of interest.

\section{References}

1. Aroswoshola, L. Global Water Intelligence Produced Water Market: Opportunities in the Oil, Shale and Gas Sectors in North America; Media Analytics: Oxford, UK, 2011; ISBN 978-1-907467-14-1.

2. Dores, R.; Hussain, A.; Katebah, M.; Adham, S.S. Using advanced water treatment technologies to treat produced water from the petroleum industry. In Proceedings of the SPE International Health, Safety \& Environment Conference, Abu Dhabi, UAE, 2-4 April 2012. SPE-157108-MS.

3. Veil, J.A.; Puder, M.G.; Elcock, D.; Redweik, R.J., Jr. A White Paper Describing Produced Water from Production of Crude Oil, Natural Gas, and Coal Bed Methane; US Department of Energy: Argonne, IL, USA, 2004.

4. Al-Ghouti, M.A.; Al-Kaabi, M.A.; Ashfaq, M.Y.; Da'na, D.A. Produced water characteristics, treatment and reuse: A Review. J. Water Process Eng. 2019, 28, 222-239. [CrossRef]

5. Alley, B.; Beebe, A.; Rodgers, J.; Castle, J.W. Chemical and physical characterization of produced waters from conventional and unconventional fossil fuel resources. Chemosphere 2011, 85, 74-82. [CrossRef]

6. Arthur, J.D.; Dillon, L.W.; Drazan, D.J. Management of Produced Water from Oil and Gas Wells. Working Document of the NPC North American Resource Development Study United States; 2011; pp. 1-32.

7. Munirasu, S.; Haija, M.A.; Banat, F. Use of membrane technology for oil field and refinery produced water treatment-A review. Process Saf. Environ. Prot. 2016, 100, 183-202. [CrossRef]

8. Liang, Y.; Ning, Y.; Liao, L.; Yuan, B. Special focus on produced water in oil and gas fields. In Formation Damage During Improved Oil Recovery; Elsevier: Amsterdam, The Netherlands, 2018; pp. 515-586, ISBN 978-0-12-813782-6.

9. Clark, C.E.; Veil, J.A. Produced Water Volumes and Management Practices in the United States; ANL/EVS/R-09-1; Argonne National Lab. (ANL): Argonne, IL, USA, 2009; p. 1007397.

10. OSPAR Commission OSPAR Recommendation 2012/5 for a Risk Based Approach to the Management of Roduced Water Discharges from Offshore Installations. Available online: https://www.ospar.org/convention/agreements (accessed on 29 May 2018). 
11. Zheng, J.; Chen, B.; Thanyamanta, W.; Hawboldt, K.; Zhang, B.; Liu, B. Offshore produced water management: A review of current practice and challenges in Harsh/Arctic environments. Mar. Pollut. Bull. 2016, 104, 7-19. [CrossRef]

12. OSPAR Commission Establishment of a List of Predicted No Effect Concentrations (PNECs) for Naturally Occuring Substances in Produced Water (OSPAR Agreement 2014/5). Available online: https:/ / www.ospar.org/convention/agreements (accessed on 29 May 2018).

13. Jiménez, S.; Micó, M.M.; Arnaldos, M.; Medina, F.; Contreras, S. State of the art of produced water treatment. Chemosphere 2018, 192, 186-208. [CrossRef]

14. Innocenzi, V.; Zueva, S.B.; Vegliò, F.; De Michelis, I. Pilot-scale experiences with aerobic treatment and chemical processes of industrial wastewaters from electronics and semiconductor industry. Energies 2021, 14, 5340. [CrossRef]

15. Morais, B.P.; Martins, V.; Martins, G.; Castro, A.R.; Alves, M.M.; Pereira, M.A.; Cavaleiro, A.J. Hydrocarbon toxicity towards hydrogenotrophic methanogens in oily waste streams. Energies 2021, 14, 4830. [CrossRef]

16. Lusinier, N.; Seyssiecq, I.; Sambusiti, C.; Jacob, M.; Lesage, N.; Roche, N. Biological treatments of oilfield produced water: A comprehensive review. SPE J. 2019, 24, 2135-2147. [CrossRef]

17. Lusinier, N.; Seyssiecq, I.; Sambusiti, C.; Jacob, M.; Lesage, N.; Roche, N. A comparative study of conventional activated sludge and fixed bed hybrid biological reactor for oilfield produced water treatment: Influence of hydraulic retention time. Chem. Eng. J. 2020, 420, 127611. [CrossRef]

18. Sharghi, E.A.; Bonakdarpour, B.; Pakzadeh, M. Treatment of hypersaline produced water employing a moderately halophilic bacterial consortium in a membrane bioreactor: Effect of salt concentration on organic removal performance, mixed liquor characteristics and membrane fouling. Bioresour. Technol. 2014, 164, 203-213. [CrossRef] [PubMed]

19. Sharghi, E.A.; Bonakdarpour, B. the study of organic removal efficiency and halophilic bacterial mixed liquor characteristics in a membrane bioreactor treating hypersaline produced water at varying organic loading rates. Bioresour. Technol. 2013, 149, 486-495. [CrossRef]

20. Fakhru'l-Razi, A.; Pendashteh, A.; Abidin, Z.Z.; Abdullah, L.C.; Biak, D.R.A.; Madaeni, S.S. Application of membrane-coupled sequencing batch reactor for oilfield produced water recycle and beneficial re-use. Bioresour. Technol. 2010, 101, 6942-6949. [CrossRef]

21. Pendashteh, A.R.; Abdullah, L.C.; Fakhru'l-Razi, A.; Madaeni, S.S.; Zainal Abidin, Z.; Awang Biak, D.R. Evaluation of membrane bioreactor for hypersaline oily wastewater treatment. Process Saf. Environ. Prot. 2012, 90, 45-55. [CrossRef]

22. Tong, K.; Zhang, Y.; Liu, G.; Ye, Z.; Chu, P.K. Treatment of heavy oil wastewater by a conventional activated sludge process coupled with an immobilized biological filter. Int. Biodeterior. Biodegrad. 2013, 84, 65-71. [CrossRef]

23. Di Bella, G.; Di Prima, N.; Di Trapani, D.; Freni, G.; Giustra, M.G.; Torregrossa, M.; Viviani, G. Performance of membrane bioreactor (MBR) systems for the treatment of shipboard slops: Assessment of hydrocarbon biodegradation and biomass activity under salinity variation. J. Hazard. Mater. 2015, 300, 765-778. [CrossRef] [PubMed]

24. Sambusiti, C.; Saadouni, M.; Gauchou, V.; Segues, B.; Ange Leca, M.; Baldoni-Andrey, P.; Jacob, M. Influence of HRT reduction on pilot scale flat sheet submerged membrane bioreactor (SMBR) Performances for oil\&gas wastewater treatment. J. Membr. Sci. 2020, 594, 117459. [CrossRef]

25. Tellez, G.T.; Nirmalakhandan, N.; Gardea-Torresdey, J.L. Performance evaluation of an activated sludge system for removing petroleum hydrocarbons from oilfield produced water. Adv. Environ. Res. 2002, 6, 455-470. [CrossRef]

26. Baldoni-Andrey, P.; Pedenaud, P.; Dehaene, P.-L.; Segues, B. Impact of high salinity of produced water on the technical feasibility of biotreatment for E \& P on shore applications. In Proceedings of the SPE International Health, Safety \& Environment Conference, Abu Dhabi, UAE, 2-4 April 2006. SPE-98751-MS.

27. Woolard, C.R.; Irvine, R.L. Treatment of hypersaline wastewater in the sequencing batch reactor. Water Res. 1995, 29, 1159-1168. [CrossRef]

28. Woolard, C.R.; Irvine, R.L. Biological treatment of hypersaline wastewater by a biofilm of halophilic bacteria. Water Environ. Res. 1994, 66, 230-235. [CrossRef]

29. Sun, C.; Leiknes, T.; Weitzenböck, J.; Thorstensen, B. Salinity effect on a biofilm-mbr process for shipboard wastewater treatment. Sep. Purif. Technol. 2010, 72, 380-387. [CrossRef]

30. Lefebvre, O.; Moletta, R. Treatment of organic pollution in industrial saline wastewater: A literature review. Water Res. 2006, 40, 3671-3682. [CrossRef]

31. Grandclément, C.; Seyssiecq, I.; Piram, A.; Wong-Wah-Chung, P.; Vanot, G.; Tiliacos, N.; Roche, N.; Doumenq, P. From the conventional biological wastewater treatment to hybrid processes, the evaluation of organic micropollutant removal: A review. Water Res. 2017, 111, 297-317. [CrossRef] [PubMed]

32. Tseng, L.Y.; Gonsior, M.; Schmitt-Kopplin, P.; Cooper, W.J.; Pitt, P.; Rosso, D. Molecular characteristics and differences of effluent organic matter from parallel activated sludge and integrated fixed-film activated sludge (IFAS) processes. Environ. Sci. Technol. 2013, 130827102639005. [CrossRef]

33. Ødegaard, H.; Rusten, B.; Westrum, T. A New Moving Bed Biofilm Reactor-Applications and Results. Water Sci. Technol. 1994, 29, 157-165. [CrossRef]

34. Cohen, Y. Biofiltration-The treatment of fluids by microorganisms immobilized into the filter bedding material: A review. Bioresour. Technol. 2001, 77, 257-274. [CrossRef] 
35. Machat, H.; Boudokhane, C.; Roche, N.; Dhaouadi, H. Effects of $\mathrm{C} / \mathrm{N}$ ratio and DO concentration on carbon and nitrogen removals in a hybrid biological reactor. Biochem. Eng. J. 2019, 151, 107313. [CrossRef]

36. Ruys, V.S.; Zerari, K.; Seyssiecq, I.; Roche, N. Study of carbonaceous and nitrogenous pollutant removal efficiencies in a hybrid membrane bioreactor. J. Chem. 2017, 2017, 4080847. [CrossRef]

37. Zerari, K.; Seyssieq, I.; Akretche, D.-E.; Roche, N. Enhancement of oxygen mass transfer coefficients in a hybrid membrane bioreactor: Enhancement of oxygen mass transfer coefficients in a HMBR. J. Chem. Technol. Biotechnol. 2013, 88, 1007-1013. [CrossRef]

38. Dong, Z.; Lu, M.; Huang, W.; Xu, X. Treatment of oilfield wastewater in moving bed biofilm reactors using a novel suspended ceramic biocarrier. J. Hazard. Mater. 2011, 196, 123-130. [CrossRef] [PubMed]

39. Hasanzadeh, R.; Abbasi Souraki, B.; Pendashteh, A.; Khayati, G.; Ahmadun, F.-R. Application of isolated halophilic microorganisms suspended and immobilized on walnut shell as biocarrier for treatment of oilfield produced water. J. Hazard. Mater. 2020, 400, 123197. [CrossRef]

40. Federation, W.E.; American Public Health Association. Standard Methods for the Examination of Water and Wastewater, 21st ed.; centennial ed; Eaton, A.D., American Public Health Association, American Water Works Association, Water Pollution Control Federation, Eds.; American Public Health Association: Washington, DC, USA, 2005; ISBN 978-0-87553-047-5.

41. Abtahi, S.M.; Petermann, M.; Juppeau Flambard, A.; Beaufort, S.; Terrisse, F.; Trotouin, T.; Joannis Cassan, C.; Albasi, C. Micropollutants removal in tertiary moving bed biofilm reactors (MBBRs): Contribution of the biofilm and suspended biomass. Sci. Total Environ. 2018, 643, 1464-1480. [CrossRef] [PubMed]

42. AFNOR NF ISO 11423-1 (T90-155) of 1997-09-01. Water Quality—Determination of Benzene and Some Derivatives—Part 1: Head-Space Gas Chromatographic Method; ISO: Geneva, Switzerland, 1997.

43. AFNOR DIN ISO 28540 of 2014-05-01. Water Quality—Determination of 16 Polycyclic Aromatic Hydrocarbons (PAH) in Water-Method Using Gas Chromatography with Mass Spectrometric Detection (GC-MS) (ISO 28540:2011); ISO: Geneva, Switzerland, 2014.

44. AFNOR NF EN ISO 11348-3 (T90-320-3) of 2009-02-01. Water Quality-Determination of the Inhibitory Effect of Water Samples on the Light Emission of Vibrio Fischeri (Luminescent Bacteria Test)—Part 3: Method Using Freeze-Dried Bacteria; ISO: Geneva, Switzerland, 2009.

45. AFNOR NF EN ISO 8692 (T90-304) of 2012-05-01. Water Quality_Fresh Water Algal Growth Inhibition Test with Unicellular Green Algae; ISO: Geneva, Switzerland, 2012.

46. AFNOR NF EN ISO 6341 (T90-301) of 2012-12-01. Water Quality_Determination of the Inhibition of the Mobility of Daphnia Magna Straus (Cladocera, Crustacea)—Acute Toxicity Test; ISO: Geneva, Switzerland, 2012.

47. AFNOR NF ISO 20666 (T90-334) of 2009-01-01. Water Quality_Determination of the Chronic Toxicity to Brachionus Calyciflorus in 48 h; ISO: Geneva, Switzerland, 2009.

48. AFNOR NF EN ISO 10253 of 2016-12-01. Water Quality-Marine Algal Growth Inhibition Test with Skeletonema sp. and Phaeodactylum Tricornutum; ISO: Geneva, Switzerland, 2016.

49. AFNOR FD ISO 14669 of 2003-08-01. Water Quality_Determination of Acute Lethal Toxicity to Marine Copepods (Copepoda, Crustacea); ISO: Geneva, Switzerland, 2003.

50. Ludzack, F.J.; Noran, D.K. Tolerance of high salinities by conventional wastewater treatment processes. J. Water Pollut. Control Fed. 1965, 37, 1404-1416. [PubMed]

51. Fatone, F.; Di Fabio, S.; Bolzonella, D.; Cecchi, F. Fate of aromatic hydrocarbons in italian municipal wastewater systems: An overview of wastewater treatment using conventional activated-sludge processes (CASP) and membrane bioreactors (MBRs). Water Res. 2011, 45, 93-104. [CrossRef] [PubMed]

52. Chakraborty, R.; O'Connor, S.M.; Chan, E.; Coates, J.D. Anaerobic degradation of benzene, toluene, ethylbenzene, and xylene compounds by dechloromonas strain RCB. Appl. Environ. Microbiol. 2005, 71, 8649-8655. [CrossRef]

53. Lewin, R.A. New herpetosiphon species (flexibacterales). Can. J. Microbiol. 1970, 16, 517-520. [CrossRef] [PubMed]

54. Sly, L.I.; Taghavit, M.; Fegan, M. Phylogenetic heterogeneity within the genus herpetosiphon: Transfer of the marine species herpetosiphon cohaerens, herpetosiphon nigricans and herpetosiphon persicus to the genus lewinella gen. Nov. in the flexibacterbacteroides-cytophaga phylum. Int. J. Syst. Bacteriol. 1998, 48, 731-737. [CrossRef]

55. Koshlaf, E.; Shahsavari, E.; Haleyur, N.; Mark Osborn, A.; Ball, A.S. Effect of biostimulation on the distribution and composition of the microbial community of a polycyclic aromatic hydrocarbon-contaminated landfill soil during bioremediation. Geoderma 2019, 338, 216-225. [CrossRef]

56. Sun, F.; Hu, J.; Zhou, Y.; Mei, R.; Wang, C.; He, Y.; Wu, W. High efficient alternating anaerobic/aerobic process for polyester resin wastewater treatment: Performance and microbial community structure. Biochem. Eng. J. 2018, 138, 121-130. [CrossRef] 